\title{
Contribution of science, technology, and innovation to post-conflict in Colombia
}

\author{
J.W. Vásquez-Capacho ${ }^{\mathrm{a}}$, Y. Garavito-Hernández ${ }^{\mathrm{b}}$, M. Castro-Castro ${ }^{\mathrm{c}}$, J. Gutierrez $^{\mathrm{d}}$, S. Rodriguez-Melendez $^{\mathrm{e}}$ \\ ${ }^{a}$ GPS, Universidad de Investigación y Desarrollo - UDI, Bucaramanga, Colombia (e-mail: jvasquez@udi.edu.co). \\ ${ }^{b}$ PORTER, Universidad de Investigación y Desarrollo - UDI, Bucaramanga, Colombia (e-mail: ygaravito2@udi.edu.co). \\ ${ }^{c}$ PORTER, Universidad de Investigación y Desarrollo - UDI, Bucaramanga, Colombia (e-mail: vice.academica@udi.edu.co). \\ ${ }^{d}$ SINERGIA, Universidad de Investigación y Desarrollo - UDI, Bucaramanga, Colombia (e-mail: jgutierrez11@udi.edu.co). \\ ${ }^{e}$ LOS MEDIADORES, Universidad Cooperativa de Colombia - UCC, Bucaramanga, Colombia (e-mail: sandrah.rodriguez@campusucc.edu.co).
}

\begin{abstract}
More than fifty years of conflict in Colombia has left a country with many needs. This article analyzes how Science, Technology, and Innovation (STI) can contribute to improving communities affected by violence in a post-conflict stage. This paper begins with an introduction focused on the processes of the generation of violence and the peace agreement, following the role of the UN in the post-conflict stage. A conceptual analysis of the actors involved in Science, Technology, and Innovation activities is also presented with one analysis of the activities of STI that can contribute to the post-conflict, continuing with some financing strategies for the activities of STI and a brief description of the legal framework STI against the post-conflict. The paper concludes with some recommendations and opportunities in this new era for the country.
\end{abstract}

Keywords: post-conflict; science community; technology adoption; innovation activities; economic development; Colombian population

\section{Introduction}

An armed conflict can be defined as the situation in which people relate in violent using weapons against other people or even with himself (4), (16). This deal with the fact that violence has always been present in human societies go through elements such as hierarchy, social inequality, intolerance, discrimination among others. According to International Humanitarian Law (IHL), there is a distinction between two types of armed conflicts, international armed conflicts, in which face two or more States; and non-international armed conflicts, between forces governmental and non-governmental armed groups, or between those groups only. The IHL treaties also make a distinction between non-international armed conflicts in the sense of article 3 common to the 1949 Geneva Conventions. The history of humanity has seen a large number of armed conflicts that have generated great massacres and violations of the human rights of the most vulnerable population; conflicts such as the world wars, the incursions of the West in the Middle East, the war in Vietnam among many others (31). However, it is clear that when the armed conflict arises within the same country or territory, the results are even more devastating because it is the same population that faces and annihilates itself. A situation that could also be called "civil war", since it involves the civilians themselves and not only the military (19), (17). In the Latin American case, Colombia is a country that has suffered for a long time the tragic effects of a non-international armed conflict, and experiences focused on the negotiated resolution of these conflicts have occurred during the last 30 years (36). Insofar as it has been an unintelligible and lengthy confrontation, the armed groups have become protagonists. Both its objectives and the use of violence have generated controversies around what actions or responses should be are implemented to deal with such violent situations (35), (38). The history of the armed conflict in Colombia shows that since the mid-sixties, groups of peasants in regions abandoned by the State took up arms as a protest against the lack of an inclusive State consistent with the attention to basic health needs, education among many other needs of these regions. In this context, armed insurgent groups such as the FARC (Revolutionary Armed Forces of Colombia), EPL (Popular Liberation Army) and the ELN (National Liberation Army) emerged (32),(39). Their left political ideologies were supported by the communist governments of Russia, China, and motivated by revolutionary actions in Cuba, Argentina, and Chile. These groups have maintained control of areas with mining and agrarian economic interest, financing their actions through the exploitation and extortion of their control areas (28), (37) and also generating conflicts between indigenous and local communities (33). With the limited presence of the State, the guerrilla groups acquired control of many areas of the country, affecting peasants, ranchers, landowners, and companies located in these regions. In response to the growth of these types of organizations (guerrillas), paramilitary groups are born. Paramilitaries or paramilitaries correspond to private armed groups or organizations that have a structure and means of financing in order to protect particular interests but do not form a formal part of the military forces of a State (21),(10). In the "First Summit of the Colombian Self-Defense Forces" held in Cimitarra (population of the Magdalena Medio in the Department of Santander, Colombia) in December 1994, it was evident that the paramilitary maneuver had no ideological presumptions, on the contrary, it was subject to the course of events 
and the realities that oppose it, as well as to a follow-up of the activities of the guerrillas. In this context, it was defined as a priority for the paramilitary groups, to analyze the politicalmilitary strategy developed by the guerrillas and to replicate it, as a raw material of their own strategic options and definitions. Subsequently, this fact became a conflict for the struggle and control of drug trafficking routes, illegal mining, usurpation of polyduct lines, among many other illicit factors of obtaining resources, permeating and bribing both the political and military sector of the country 11 These new actors and their procedures and strategies of struggle added other elements to the conflict, making it much more complex to solve because multiple interests with dissimilar actors came into play, and a single common aspect: war, becoming this the favorable scenario for enrich a few and keep affected communities away from opportunities for progress (29), (25),(24). This generation of violence that has affected different regions of the country, increases with factors such as lack of education and job opportunities, facilitating the influence of criminal gangs (financed by drug trafficking) in youth, making them participate in activities outside of the law, such as smuggling, illegal mining, kidnappings, hired killers, assassinations and a variety of irregular business modalities (18), (30),(22), (1). After of a conflict that has passed more than fifty years, the country reaches a peace agreement with the largest guerrilla group in Colombia (5), the FARC (Revolutionary Armed Forces of Colombia), which surrendered their weapons and became a legally constituted political party under the Peace Agreements signed on September 26, 2016 ${ }^{2}$ This peace agreement sows its foundations in 6 fundamental pillars: (i) policy and sustainable development, (ii) political participation, (iii) solution to the problem of illicit drugs, (iv) point about the victims of the armed conflict, (v) ) end of conflict and (vi) implementation, verification and endorsemen 3 , which in turn arise from 6 points in common between the FARC-EP and the national government during the negotiation process $(8)$ :

1. The construction of peace is a matter of society as a whole.

2. Respect for human rights is a goal of State that must be promoted.

3. Economic development with social justice and in harmony with the environment is a guarantee of peace and progress.

4. Social development with equity and well-being, including large majorities, allows growth as a country.

5. Colombia in peace will play an active and sovereign role in regional and world peace and development.

6. It is important to expand democracy as a condition to achieve solid foundations of peace.

${ }^{1}$ Centro de memoria historica, http://www.corteidh.or.cr/tablas/ r31474.pdf

http://www.altocomisionadoparalapaz.

gov.co/procesos-y-conversaciones/Paginas/ Texto-completo-del-Acuerdo-Final-para-la-Terminacion-del-conflicto aspx

http://www.altocomisionadoparalapaz.gov.co/ procesos-y-conversaciones/Documentos $\% 20$ compartidos/ 24-11-2016NuevoAcuerdoFinal.pdf
This new scenario leads to compromises and the search for tools on the part of those involved in the conflict, in pursuit of the achievement of "stable and lasting" peace. In this way, activities related to education, productive transformation, economic and social development and the generation of new opportunities constitute bets, which need to be supported by science, technology, and innovation. Tools that contribute to the transformation of communities in post-conflict stages, by allowing the development of productive units that guarantee sustainable societies in the future in the different regions of the country. The escalating incidence of technological advancements has allowed those responsible for designing policies and strategies to think about the emergence of technology for proactive planning, then technology and innovation policies have been at the core of economic development in different parts of the world since the 1950s (6), now focusing in a new Responsible Research and Innovation (RRI)(14) for the performance and sustainability in developing countries(9). For example, the Agricultural Technology Demonstration Centre (ATDC) is recognized as a new model to persevere the sustainability of Chinese foreign aid to African countries (41).

This paper is divided into 6 sections. Section 1 is the introduction. Section 2 presents a brief description of the rol of the ONU in the post-conflict. Section 3 deals with a general review of the actors involved in activities of Science, Technology, and Innovation (STI) in Colombia. Section 3 presents some important activities of STI that can contribute to the postconflict. Section 4 exposes financing strategies for activities of Science, Technology, and Innovation in the post-conflict. Section 5 presents a brief description of the legal framework STI against the post-conflict. Section 6 corresponds to some recommendations and opportunities in this new era for the country.

\section{UN interventions in the pos-conflict stage}

Political missions are part of the options that the United Nations Security Council has to play its main role in maintaining international peace and security. These are characterized by being versatile since they can be used at any time in conflict - from prevention to post-conflict situations - and can be used in various shapes and sizes. Among its main functions are good offices, mediation or facilitation is given a political commitment. Their mandates generally cover a period of six months and the Security Council, through the analysis of reports provided by the Secretary-General, reviews their continuation, termination or possible modification. In this way, it plays an active role in monitoring the fulfillment of the tasks and objectives of the mission ${ }^{4}$. In the post-conflict in Colombia, UN created the United Nations Verification Mission, which will verify the political, economic and social reinstatement; and security guarantees for the members of the FARC, their families and for the communities 5 Once this mission is created, it will be charged with https: \//zero.uexternado.edu.co/

la-participacion-de-la-onu-en-el-posconflicto-en-colombia/ https://nacionesunidas.org.co/onu-colombia/ mision-de-verificacion/ 
verifying the following two points of the Final Agreement 6

Point 3.2 of the Agreement: Reintegration of FARC into civilian life - economically, socially and politically.

"Laying the foundations for the construction of a stable and lasting peace requires the effective reintegration of the FARCEP into the social, economic and political life of the country. The reincorporation process reaffirms the commitment of the FARC-EP to contribute to the termination of the armed conflict, become a legal political subject and contribute decisively to the consolidation of national reconciliation, peaceful coexistence, non-repetition, and to transform the conditions that have allowed the origin and persistence of violence in the national territory. "The contents of the Agreement to be specifically verified are:

- Economic and social reinstatement.

- Guarantees for the new party or political movement that emerges from the transit of FARC to political life.

\section{- Political reinstatement}

Point 3.4 of the Agreement: Security guarantees and fight against criminal organizations and behaviors. "Agreement on security guarantees and the fight against criminal organizations and behaviors responsible for homicides and massacres, that attempt against human rights defenders, social movements or political movements or that threaten or threaten people involved in the implementation of the agreements and the construction of peace, including criminal organizations that have been named as successors of paramilitarism and its support networks." The contents of the Agreement to be specifically verified are:

- Protection and security measures, personal and collective.

- Integral Security System for the exercise of the policy, especially for members of FARC and their families.

- The Comprehensive Security and Protection Programs for communities and organizations in the territories.

The participation of the UN in the Colombian post-conflict has budgetary and personnel restrictions, but this can be effective for the progress in consolidating the peace process. The participation of an international organization such as the UN can not only give confidence to the parties and the civilian population, but also an experience to obtain good results from such an operation. Indeed, the continued review of the mission by the secretary-general and the determination of a clear mandate can make it more efficient and effective. The scenario of a country in peace allows develop many activities to improve the regions affected by violence, therefore activities related to science, technology, and innovation can help to construct a sustainable post-conflict. In the next section, a brief description of the actors involved in this type of activity is described.

https://colombia.unmissions.org/mandato

\section{Actors involved in Science, Technology, and Innovation activities - STI -}

The technological innovation activities, according to the Frascati Manual, correspond to the set of scientific, technological, organizational, financial and commercial stages, involving the investments that they carry or that they try to lead to the implementation of new or improved products and processes (11). R\&D (Research and Development) is an activity that can be carried out in different phases of the innovation process, which is also taken as a basis for the generation of creative ideas as well as solving the problems that may arise at any stage from a project to its completion. As innovative activities, all the scientific, technological, organizational, financial and commercial operations are cataloged, which consequently transfers the introduction of innovations. Some of these activities are innovative in themselves, others are not new but are necessary for the introduction of innovations. Therefore, innovation activities also include $R \& D$ activities that are not directly linked to the introduction of a particular innovation (OECD, 2015) In Colombia, the Administrative Department of Science, Technology, and Innovation - COLCIENCIAS - has recognized the most important needs that the country has been showing in Science, Technology, and Innovation during the last years. Leading to the creation of a guide whose objective is: "to guide the identification, formulation and evaluation of science, technology and innovation projects (STI), and of projects from other sectors that include Science, Technology and Innovation activities (ASTI), that are financed with investment resources of the national government, the territorial entities, the General System of Royalties -SGR- and other sources of public and private resources". Among the possible research activities and experimental development, there are 8

The basic research activities include experimental or theoretical works that are undertaken mainly to obtain new knowledge about the theoretical foundations of the phenomena and observable facts, without still involving in their results a specific application or use, independently of the area of knowledge.

Applied research activities are activities carried out to acquire new knowledge, directed towards a specific practical objective. Applied research is undertaken to determine the possible uses of the results of basic research, or to determine new methods or ways to achieve predetermined specific objectives.

Technological or experimental development activities correspond to systematic works that take advantage of existing knowledge obtained from research and/or practical experience and is aimed at the production of new materials, products or devices; to the start-up of new processes, systems, and services, or the substantial improvement of existing ones.

Innovation activities concern the incorporation and appropriation of technology or science to include a new product or

7 https://www.oecd.org/about/publishing/ colombia-politicas-prioritarias-para-un-desarrollo-inclusivo. pdf

https://www.colciencias.gov.co/sites/default/files/ ckeditor_files/politiciadeactores-snctei.pdf 
process, or a new modification or use the same ones that improve it in some way. It includes designs, technical manuals, infrastructure acquisitions, machinery, and equipment, as well as other activities carried out in order to implement innovations. They also belong to this category, the acquisition of patents, non-patented inventions, licenses, designs, brands and software packages; as well as the actions to introduce changes in the organization of the production process that reduce downtime, waste, process times or similar. Innovation activities are also those related to the commercialization of technologically new or improved products and specialized training in core technologies for the activity of the entity. As complementary activities to the activities of STI, we can have activities of scientific diffusion, formation, technological services, consultancy, and consultancy, as well as the social appropriation of knowledge. These complementary activities should not demand a large volume of human, financial or infrastructure resources. In Colombia, a project classified as STI corresponds to a coherent and comprehensive set of science, technology and innovation activities that seek to achieve a final goal through specific objectives, using a defined methodology in a coordinated and interrelated manner. in a period of time, which can be based on key elements such as tools, human resources, support of guidelines and guidelines of senior management, essential technological or physical resources, in addition to previously estimated financial resources (COLCIENCIAS, Typology of projects) ${ }^{9}$

The administration and other support activities in STI are activities aimed at gathering and managing funds for STI that contribute to the support of ASTI carried out by entities such as ministries, research organizations, foundations, and other nonprofit organizations. To define the relationship of the main activities in STI and complementary activities in a practical way, the Technological Development Level or TRL can be used as a reference (Technology Readiness Level) (20). These levels are distributed in nine steps, from the observation of the basic principles (TRL1) to the deployment, production, and commercialization of new products (TRL9). Fig. 1](Prepared by the authors based on annex 13 of Colciencias 10 presents a relationship between the activities of STI together with the levels of technological development.

In this figure, we can see how from the basic research one must have the vision to where the theoretical proposal could be applied, focusing especially on the possible towards a welldefined industrial solution. In this initial part is where the industry-academy relationship is very important in order that the industrial and productive sectors of the regions define the most important thematic and technical needs. These being the inputs of the research groups together with their researchers to plan their research projects. Following the activities, the applied investigation goes until validating the new theoretical concepts in the laboratory doing experimental tests. Technological

"https://www.colciencias.gov.co/innovacion/ beneficios-tributarios/tipologia-proyectos

it https://ww.colciencias.gov.co/sites/default/files/ upload/convocatoria/anexo-13-niveles-madurez-tecnologica-conv pdf

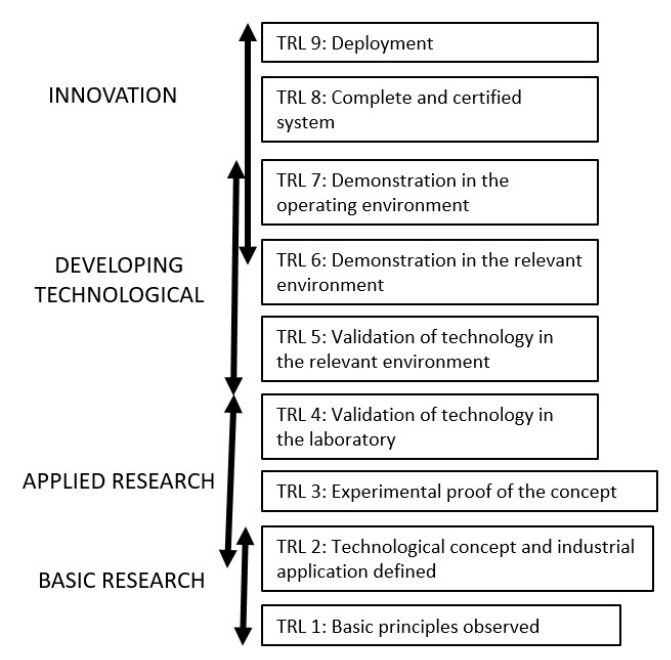

Figure 1: Relationship of STI activities with technological maturation levels.

development activities lead to the demonstration of theoretical concepts in the relevant environments to the operating environment. Culminating with activities related to innovation in which a viable minimum product can be mass produced for its incursion into the market. The activities described above can be carried out by a group of specific actors that must be recognized by the National System of Science, Technology, and Innovation in Colombia. Principally, the researchers are professionals involved in the conception or creation of new knowledge, products, processes, methods, and systems, and/or in the management of the respective projects (OECD, 2015). Thus, understanding the research group as the set of people (researchers) who interact to investigate and generate knowledge products in one or several subjects, according to a work plan of short, medium or long term (tending to the solution of a problem). Both researchers with their groups can be part of research centers or institutes, Technological Development Centers (CDT), science centers, R\&D+i (Research, Development and innovation) Units of a company, highly innovative companies, Incubators of Technology-Based Companies (IEBT) and Innovation and Productivity Centers (CIP).

The aforementioned gives us a framework for the definition and structuring of projects that contribute to the post-conflict situation in Colombia, where financing programs derived from international cooperation can also be analyzed.

\section{Activities of STI for the post-conflict}

Parallel to the conflict, Colombia has been working for more than twenty years in favor of local and regional development, the formation of citizenship for the formulation of proposals, the humanitarian attention to victims, the reintegration of demobilized, the education of adolescents and young people for the Peace and its reintegration (34), (12). This has been the work of the public and private sector, community organizations 
and international agencies (considered as valuable antecedents to ensure success), which now with the maturity, rationality and positive perspectives of the STI will be able after an agreement of peace to the impact of the direct way like never before had been achieved. This is where the action of science, technology, and innovation should take into account current and future elements of the context such as:

- The territorial approach, that is, each territory or region must include and develop its own STI plans according to their needs and priorities defined in the regional commissions on science, technology, and innovation.

- Demand perspective of local actors. For the development of these plans, universities, colleges, TIC secretariats (Information and Communication Technologies) among other entities of each region should be involved.

- The great diversity of society, economy, culture, and the environment; In this context, all STI plans must involve guilds, cultural and environmental entities in order to make the definition of projects and needs more inclusive.

- Citizen participation in the evaluation of technology and knowledge; Involving the society in the evaluation of the STI plans requires informing and keeping abreast of all the activities carried out in this field.

- Support function of science, technology and innovation to the construction of Peace; there are several topics within which we can see:

- Training in robotics, industrial automation, Internet of Things, data analytics, etc. In this order, there is a need to offer to these communities affected by violence, reinserted and vulnerable populations, training programs in technology. Not only training in bakery or carpentry but also other alternatives where the young population (Generation Y) can train in the use and management of computer tools that allow them to participate in the development of their communities. In addition to training them in skills to work in companies in the mining and energy sector, OIL\&GAS that are located in the regions. It is here that virtual education becomes more relevant and is integrated into the accumulation of support tools necessary to facilitate access to knowledge in remote communities of large cities.

- Alternative energies in the regions, photo voltaic systems, wind power, etc. The use of renewable energy is of great importance for the country, especially in regions where access to conventional energy sources is not adequate. This alignment with economic policies will produce a high impact, not only at the level of productivity but also against climate change.

- Drinking water and basic sanitation (water quality monitoring). In many regions of the country, access to potable water and efficient basic sanitation systems are not available. Having an efficient control and monitoring of the water conditions will allow continuous development and guarantee the prosperity of the region.

- Improvement of productive chains, industrialization of agriculture. Including new technologies and making an efficient transformation of the agricultural industry where the communities are involved will guarantee a sustainable development of the regions. Allowing it to be produced efficiently and to be able to serve national to international markets with quality products and in many cases transforming them to give them an added value that can make them more competitive.

- Business support. There are a big number of entrepreneurship opportunities from the regions. Opportunities in the design and development of new agricultural products, promotion, and promotion of ecological tourism (27), design, development, and marketing of handicrafts over the internet, among many other circumstances that allow sustainable development of communities.

- The concentration of R\&D capabilities (Research and development) in a few cities; this due to the little training and generation of skills of the people of the regions. It is more than certain that in all regions, especially young people are able to receive training and technological subjects. But the lack of effective strategies and programs framed in a country project makes it difficult to develop $R \& D$ in regions far away from large cities.

- Institutional flexibility and the need for institutional innovation. This is reflected in a large number of bureaucratic procedures for carrying out projects. The system needs independent and dynamic management where royalties do not end up making roads or building theme parks with little impact on the development of the regions, as well as the construction of white elephants that are seen throughout the country.

- Education, business innovation and universities. It is recognized that people who develop R\&D activities with higher educational level enriches innovation, therefore, companies and governments should favor and develop training programs that encourage creativity and business innovation. This can be achieved through the university company approach, which allows access to scientific knowledge, technical equipment or new technological options that favor innovation in companies (26).

Thus, the empowerment of local and regional actors have been an important participatory territorial approach in integral rural development (Misión Rural, 2015) 11 , which justifies, in

${ }^{11}$ https://colaboracion.dnp.gov.co/CDT/Prensa/DOCUMENTO\% 20MARCO-MISION . pdf 
turn, changes in the management and realization of science, technology, and innovation. Emphasizing that the most important projects will be defined in large part by the inhabitants and territorial organizations, in dialogue with researchers, businessmen and public servants. This also contrasts with the concentration of researchers and innovators in the five main cities (Bogotá, Cali, Medellín, Barranquilla, and Bucaramanga) in the face of the dispersion and remoteness of the conflict areas. This is due to the fact that the STI system has not proposed strategies for researchers from large cities to contribute jobs to remote regions within a macro region's plan. For example, if from Bogota the Meta, Casanare and San Andres or from Bucaramanga support Cesar, Magdalena Medio and Arauca. Many works can be approached from these regions with relevant scientific support from researchers in capital cities. So, there is much to be done, there are interested people and apparently sufficient resources for royalties among other financing mechanisms where it is necessary to strengthen the management and effective organization of the STI system in the country. The industry-academy-state relationship has been the fundamental axis that allows the sustainable development of a country based on science, technology and innovation activities. This being a topic that has been discussed in Colombia for more than ten years, still continuing to explore alternatives for the strengthening of this relationship (40).

With a country in peace, opportunities open exponentially. New and fresh ideas that allow an adequate approach to innovation is what the country needs, young researchers and scientists, contributing to the integral development of society. The effective utilization of the resources associated with the STI, the monitoring of the projects, and the analysis of the investments of the entrepreneurship funds that the system uses, are important activities to guarantee the sustainability of the national system of science, technology, and innovation (3). Fig. 2 shows, according to the type of executing agency, in what proportion the national investment in ASTI has been managed It can be observed an increase of more than $20 \%$ in the percentage of investment of companies in ASTI and a tendency towards the decrease of the governmental entities. The investments of the centers of research and technological development have remained stable for the last almost 20 years, and a tendency to decrease by the institutions of higher education. This reflects that the policies in science, technology, and innovation that have been implemented in Colombia do not affect an increase in the percentage of investment of key entities such as universities and centers for technological development and research (7). Although the increase in investment in companies is evident, this is because the productive sector carries out projects and ASTI most of the time on its own initiative, with minimal interaction with universities and technology centers. On the other hand, within national policies for the recognition, for example, of innovation and production centers, the fulfillment of many requirements is required, such as having resources to finance them, carry out projects and tangible results without having any financial support from the government.

\footnotetext{
12 https://ocyt.shinyapps.io/odocyt_v1/
}

Regarding the financing of ASTI related to the post-conflict, in 2015 COLCIENCIAS opened a call (717) for the realization of a research program on politics, state and power relations in the post-conflict ${ }^{13}$. With the aim of formulating, designing and executing a research program around the problem of governance in a post-conflict scenario, developed by an alliance, to contribute to the peace-building process of the country, as a priority needs of Colombian society. The result of this call was deserted because none of the participants fulfilled all the requirements, such as having a researcher from a group classified A or A1 ${ }^{14}$ In 2017, COLCIENCIAS opened the call (790): "Ideas for Change - Science and STI for Peace", with the aim of supporting processes of social appropriation of the STI that develop solutions from Science, Technology and TIC, to respond to the challenges proposed in ten (10) Subjects of Collective Repair, articulated to the objectives of sustainable development and integral reparation plans 5 . Funded projects such as: Management and treatment of water through appropriate technologies in the inspection of La Cooperativa-Mapiripán (Meta) with social appropriation of knowledge through TIC's; Improvement of the aqueduct service in La Secreta: A prospective study using TIC's; Science, TIC and Marketing as a collective strategy aimed at improving the quality of production and sale of citrus in Simacota - Santander: App Production Module. Delivering resources in the order of 180 million Colombian pesos (approximately US $\$ 60,000$ ) for each project. The projects of this call were made, only and exclusively, for ten municipalities of 1101 of the Colombian territory, a coverage of less than $1 \%$ of the national territory. In the year 2018, from COLCIENCIAS the call (804) was made, corresponding to a Regional Call for R\&D projects that contribute to the strengthening of virtual training in the Department of Antioquia, Occident ${ }^{16}$ Carried out to contribute to the generation of knowledge through the execution of research projects with functional technological developments, which address issues of virtual training for higher education in the Department of Antioquia. Allowing the realization of 21 projects with resources awarded from 480 to 700 million Colombian pesos (US \$ 150,000 to US \$220,000) for each project. The policies for the financing of these projects try to solve important problems in the regions of Colombia, although apparently, these resources do not reach to have greater coverage of the Colombian territory, the role of the business sector both private and public play an important role in the postconflict as support for the financing of the ASTI.

\footnotetext{
13 https://www.colciencias.gov.co/convocatorias/ investigacion/convocatoria-para-un-programa-investigacion-sobre-pol

${ }^{14}$ https://www.colciencias.gov.co/sites/default/files/ upload/convocatoria/4._anexo_1._documento_conceptual_ del_modelo_de_reconocimiento_y_medicion_de_grupos_de_ investigacion_2018.pdf

is https://www.colciencias.gov.co/convocatorias/ mentalidad-y-cultura/convocatoria-ideas-para-el-cambio-ciencia-y-ti

${ }^{10}$ https://www.colciencias.gov.co/convocatorias/ investigacion/convocatoria-regional-proyectos-id-que-contribuyan-al
} 


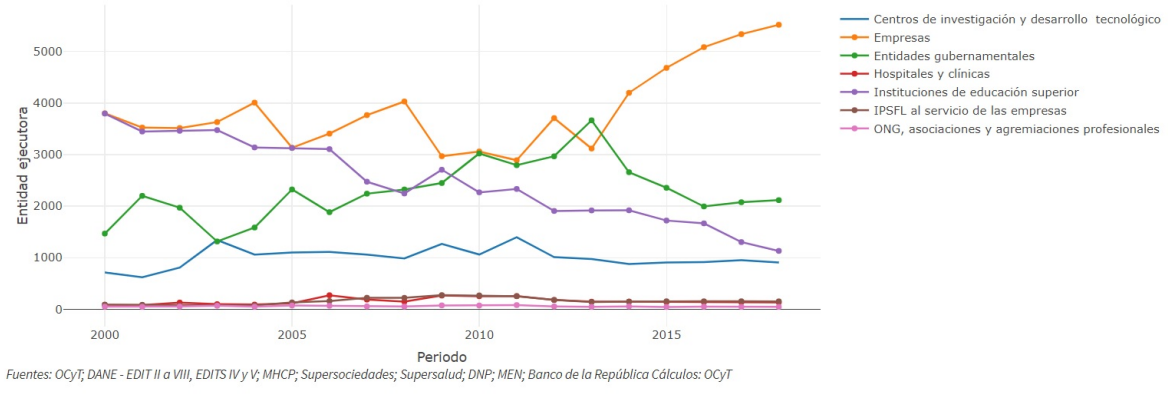

Figure 2: Percentage of national investment in ASTI by type of executing entity. Source: OCyT; DANE - EDIT II a VIII, EDITS IV y V; MHCP; Supersociedades; Supersalud; DNP; MEN; Banco de la República

\section{Financing strategies for ASTI in the post-conflict in Colombia}

At the governmental level, in recent years resources have been set aside to finance projects based on science, technology, and innovation that can be applied to solving problems in populations that are victims of the conflict in Colombia. As previously stated, COLCIENCIAS allocating resources for the realization of calls and the DNP (National Planning Directorate) allocating the resources of the General Royalty System for the fund of science and technology and allocations for peace ${ }^{17}$. Similarly, ministries such as the Ministry of Information Technology and Communications (MinTIC), the Ministry of Industry and Commerce, SENA (National Apprenticeship Service), Innpulsa, Ministry of Agriculture, departmental secretariats, governorships, and mayors are part of government entities that can finance ASTI in the post-conflict nationwide ${ }^{18}$ In relation to international financing, in Colombia, during the peace talks between President Andrés Pastrana and the guerrillas at the end of the 1990s, the strategy was put forward: Diplomacy for Peace to get the support of the international community. As a result, after three donor tables between 2000 and 2001 in Madrid, Bogotá, and Brussels, the country managed to increase cooperation resources from 100 million dollars a year to 500 million dollars on average. This was achieved under the figure of Official Development Assistance (ODA). Despite the rupture of the dialogues in February 2002, the main donors continued to provide resources to Colombia, making it one of the largest holders of international cooperation resources in the region (15). It is common knowledge that international attention to "fragile states" increased exponentially after the events of September 11, 2001. This approach was pointed out in the US National Security Strategy 2002 and shortly after is reflected in the policy statements of the Organization for Economic Cooperation and Development (OECD), as well as in the declarations of the OECD itself and the World Bank. While the military intervention was the most visible instrument used to selec-

17 https://sicodis.dnp.gov.co/Reportes/ EstadoPresupuestalSGR_v6.aspx

${ }^{i c h}$ http://www.colombiacompetitiva.gov.co/sncei/Paginas/ quienes-somos.aspx tively intervene in "fragile states" after 9/11, official development assistance from the OECD (ODA) to "fragile states" also increased dramatically, from US\$ 5.8 billion in 2000 to US \$ 46.7 billion in 2009 (2). What is less known is that the opinions of the donors of the "fragile states" and of their political options in these types of situations have also evolved significantly in the last decade. Through the development of the Aid Committee (CAD) and the OECD, the working groups became the International Network on Conflict-Affected and Fragile States (INCAF), donors generate a group of norms and guidelines to guide international commitment in fragile contexts (International Organization for Work, 2017

In Colombia, for a period of time, the main international donors determined resources to the country through programs that in most cases focused on supporting the elimination of causes. Causes such as: lack of clarity in the ownership of land, political participation, drug trafficking among others. Also assume the consequences of the Colombian conflict, in areas such as victim care or reintegration. The United States through Plan Colombia, and the European Union through the Peace Laboratories, with their own resources and adding to the other European countries, became the main donors. Although the resources of the donors were increased, both the Plan Colombia and the Peace Laboratories demonstrated a different vision and position in the face of resolving the conflict. This marked the way in which the programs were elaborated and executed among the main donors, differing in their way of acting. The idea of "development" outlined in the field of international cooperation shows a profile that has or manifests several facets. This as a result of the multiple variations to which it has been subjected, in principle focused on the notion of material progress, concentrated an eminent economic dimension to the point of being restricted to a mere indicator of a country's productivity (13). In support of the post-conflict STI processes, resources can be sought with entities such as the Spanish agency for international cooperation, the Norwegian Agency for Development Cooperation, the Inter-American Development Bank, the Regional Fund for Digital Innovation in Latin America, among many others. entities with which there is the possibil-

${ }^{19}$ https://www.ilo.org/wcmsp5/groups/public/---ed_emp/ documents/instructionalmaterial/wcms_559101.pdf 
ity of managing resources that serve for the implementation of STI projects that allow the economic development of vulnerable communities belonging to developing countries. Investments in ASTI, on average, as a percentage of GDP(Gross Domestic Product) have been $0.47 \%$, and only $0.20 \%$ in specific R\&D activities during the last ten years in Colombia 20

Although most of it is carried out by the public sector, participating on average with $58.4 \%$, the private sector contributed $37.5 \%$, as well as international actors, contributed the remaining $2.1 \%$ (CONPES 3834) In Colombia, it is proposed to reach $1 \%$ of investment in ASTI as a percentage of GDP, establishing a greater effort from the private sector, which should contribute close to $50 \%$ of the investment. For the private sector, the benefits granted to STI in Colombia are regulated by the National Council of Tax Benefits, which is responsible for establishing the criteria and conditions for qualifying projects as scientific, technological and innovation (Law 1286 of 2009) ${ }^{22}$ In this way, the ASTI that can be carried out from the private sector is a fundamental part of the national system of science, technology, and innovation and this is where an important strategy lies in the creation of technological institutes as centers of innovation and productivity that help the business sector and productive access to these benefits.

\section{Legal Framework STI against the Post-Conflict}

Science, technology, and innovation contribute to the postconflict stage in Colombia in the processes of reintegration and development of the society that was immersed in the conflict, requiring a normative framework that serves as a support for those processes in this stage. Although it is true, the three public authorities of the Colombian State have intentionally sought an opportunity with the STI to contribute to the postconflict stage to improve education, the development of the agro-industrial sector, tourism, water conditions, basic sanitation, and energy. renewable as some of the activities requiring a timely legal foundation that provides effectiveness and efficiency in search of a "stable and durable" peace. In this way, it is important to address the issue to international standards as they are; the Universal Declaration of Human Rights, the Charter of the United Nations, and the norms of national order such as those enshrined in the 1991 Constitution ${ }^{23}$. especially the Preamble and article 22 that includes a "non-tutelable" right such as "La Paz" being a duty and an individual right (iusfundamental) of mandatory compliance that constitutes the foundation of political and legal order as expressed by the Constitutional Court in decision C-007-2018 (Constitutional Court, MP Diana Fajardo Rivera, 2018 stating that the idea of peace is

\footnotetext{
26 https://ocyt.shinyapps.io/odocyt_v1/

${ }^{21}$ https://www.colciencias.gov.co/sites/default/files/ upload/conpes3834-beneficiostributarios.pdf

${ }^{2}$ https://www.colciencias.gov.co/sites/default/files/ upload/reglamentacion/ley_1286_2009.pdf

http://www.secretariasenado.gov.co/senado/basedoc/ constitucion_politica_1991.html

${ }^{24}$ http://www.corteconstitucional.gov.co/relatoria/2018/ C-007-18.htm
}

linked to the construction of a just order, respectful of rights and democratic, where "measures aimed at the pursuit of this right (peace) and overcoming the armed conflict, have an undeniable constitutional support." I conclude that you should not look at yourself in isolation. On the contrary, it must go hand in hand with "justice", called transitional, that is, a justice that allows to go from a moment of armed conflict to one of peace where the government has shown interest in improving the development of society in post-conflict, implementing and strengthening the STI as one of the strategies to obtain such long-awaited peace. So things and in order to improve the development of society, in 2012 the Legislative Act 01 (Single System of Information Juriscol, 2012 $\sqrt{25}$ was proffered, whose objective was to design a comprehensive and coherent strategy for the effective satisfaction of the rights of the victims, and through which created the transitory article 66 in the National Constitution establishing instruments of transitional justice (Constitutional Court, 2013) of judicial or extrajudicial character that allowed to guarantee the duties of the state of investigation and sanction by means of the creation of a statutory law. Subsequently, in order to achieve the restoration of peace and justice with the CTel in 2015, article 116 of Law 1769 of $2015 \sqrt{26}$ was issued through which the Fund for Environmental Sustainability and Sustainable Rural Development in areas was created. affected by the conflict, with the goal of investing in environmental sustainability projects and/or rural development in areas with development gaps where the State needs to increase its presence, thus reflecting the intentionality of the government against the development in STI.

\section{Conclusion}

The post-conflict stage in Colombia marks a new era in the history of the country, however this should not be understood as the end of the conflict, without the final stage to overcome it: "In it there are innumerable requests and challenges to achieve that be successful and final in the construction of a lasting and stable peace. Consequently, the final or post-conflict stage must be understood beyond the cessation of hostilities or the cessation of direct violence" $(\underline{8})$. This shows that the great number of opportunities that open up with a country in the post-conflict stage and the eventual peace situation are endless. In this way, science, technology, and innovation can adequately contribute to the processes of reintegration and development of communities before the post-conflict. Contributions in education, development of agro-industry, tourism, improvement of water conditions, basic sanitation and renewable energies are some of the activities supported in STI that can greatly contribute to the successful development of regional national plans: (i) infrastructure and adequacy, (ii) social development, and (iii) stimulus

\footnotetext{
25 http://www.altocomisionadoparalapaz. gov.co/desarrollos-legistlativos-paz/ marco-juridico-para-la-paz/Documentos $\% 20$ compartidos/ Acto-Legislativo-N-01-del-31-de-julio-de-2012-4.pdf

${ }^{2}$ http://www.secretariasenado.gov.co/senado/basedoc/ley_ 1769_2015.html
} 
to productivity, as well as development programs with a territorial approach $(\mathrm{PDET})^{27}$, defined by the Havana agreement for the post-conflict phase in Colombia. The state, the universities and the productive sector must work aligned in order to rebuild a country in which violence is not generated again due to lack of opportunities and adequate conditions that allow the sustainable development of the communities. Within the commitments of the State and the new ministry of science, technology, and innovation, is to generate favorable conditions for projects of STI contribute to the development of the country in this post-conflict stage. It also supports the creation of institutes and innovation centers that allow dynamic interaction between academia, industry, and government. One could think of regional institutes that give support and support to the needs of large, medium and small companies, allowing an appropriation of technology and knowledge in an efficient and constant manner. A scenario where companies and the productive sector are responsible for the implementation of the solutions offered by the institutes. It is suggested that at the beginning (3-5 years) these institutes be subsidized by the State in order to guarantee their strengthening while they become self-sustaining. And it is there, in these technological institutes where job opportunities are for the new generation of Ph.D.'s that are being formed. It should not be the companies that have to make economic efforts to hire doctors exclusively, they are the institutes where these scientists must work together with the universities to provide solutions to the productive sector of the country.

Below are other recommendations so that from the perspective presented in this article, the projects and activities in STI have a better impact: COLCIENCIAS in 2013 had a budget of around 430 billion Colombian pesos (approximately US \$ 135 million), in 2018 the annual budget was around 337 billion Colombian pesos (approximately US \$ 105 million) ${ }^{28}$, reducing by almost $22 \%$; meanwhile, for example, in 2019 Spain invests 1240 million euros dedicated exclusively to a Center for Industrial Technological Development ${ }^{29}$. The Colombian case appears to be inconsistent with a developing country that needs to increase its investment in STI. It is suggested a significant increase in the budget for this entity, in addition to the support from the administration and articulate all public resources available to STI, for example, resources from other ministries such as MinTIC, Industry and Commerce, Environment, among other entities such as Innpulsa, SENA, Governments, and mayorships. On the other hand, allow the participation of more research groups, for example from category B and not A/A1 as stipulated in several calls related to the post-conflict. Category A or A1 groups are required, for example, to have a registered paten ${ }^{30}$ and this requirement should not be a condition for par-

\footnotetext{
27 http://www.altocomisionadoparalapaz.gov.co/ herramientas/Documents/Nuevo_enterese_version_6_Sep_final_ web.pdf

${ }^{20}$ https://www.colciencias.gov.co/la-ciencia-en-cifras/ presupuesto-colciencias

${ }^{20}$ http://www.sepg.pap.hacienda.gob.es/sitios/sepg/es-ES/ Presupuestos/PGE/ProyectoPGE2019/Paginas/ProyectoPGE2019. aspx

${ }^{3}$ https://www.colciencias.gov.co/sites/default/files/
}

ticipating in a call for post-conflict projects. It is suggested to generate open calls to all the municipalities of the country or wider areas in order to generate a greater impact in the regions of the country. The current increase of professionals with doctorates should be taken advantage of, inviting them to create a bank of projects eligible for peace, which can focus on achieving the generation of new sources of employment. In the new approaches that can be given to the policies of science, technology, and innovation in Colombia, the processes of STI should be stimulated in the companies and productive sectors of the country. This, articulating the academy and the productive sector with the State including an efficient administration of resources. The General System of Royalties manages an important part of resources with accumulated values since 2012 to more than 4 billion Colombian pesos to the science and technology fund and 2 billion in allocation for peace (around US \$ $2,000$ million $)^{31}$ For the allocation of these resources, transparency should be guaranteed and could be extended with more instruments where policies such as tax incentives are used by many more beneficiaries and royalty projects are not managed by political interests for the economic benefit of the candidate or politician of turn. On the other hand, a percentage of International Cooperation resources can focus on training citizens for peace; also develop "sponsor programs" where examples of successful cases and improvements in the post-conflict are taken. The efficient and timely use of STI resources will allow the regions of the country to be gradually taken to prosperous and sustainable spaces in peace. We are already in the fourth industrial revolution and to be competitive we have to work hard on the appropriation and transfer of technology. Especially in sectors and populations affected by the conflict, looking for a better future for the country based on an innovation policy following the example of countries like South Korea, Singapore, Vietnam, Israel and India that have committed important resources for their scientific development and technological (23), allowing new generations to be promoted based on science, technology, and innovation and nowadays be an example of developed countries.

\section{References}

[1] María Alejandra Arias, Ana María Ibáñez, and Andrés Zambrano. Agricultural production amid conflict: Separating the effects of conflict into shocks and uncertainty. World Development, 119:165 - 184, 2019.

[2] Stephen Baranyi and Marie-Eve Desrosiers. Development cooperation in fragile states: filling or perpetuating gaps? Conflict, Security $\mathcal{E}$ Development, 12(5):443-459, 2012.

[3] Julio A. Berdegué, Fernando Carriazo, Benjamín Jara, Félix Modrego, and Isidro Soloaga. Cities, territories, and inclusive growth: Unraveling urban-rural linkages in chile, colombia, and mexico. World Development, 73:56 - 71, 2015. Growth, Poverty and Inequality in Sub-National Development: Learning from Latin America's Territories.

[4] Philippe Le Billon. The political ecology of war: natural resources and armed conflicts. Political Geography, 20(5):561 - 584, 2001.

\footnotetext{
upload/convocatoria/4._anexo_1._documento_conceptual_

del_modelo_de_reconocimiento_y_medicion_de_grupos_de_ investigacion_2018.pdf

Si https://sicodis.dnp.gov.co/Reportes/

EstadoPresupuestalSGR_v6.aspx
} 
[5] Jurgen Brauer and Juan F. Vargas. Colombia: Introduction to a special issue of defence and peace economics. Defence and Peace Economics, 23(2):107-108, 2012.

[6] Serhat Burmaoglu, Olivier Sartenaer, and Alan Porter. Conceptual definition of technology emergence: A long journey from philosophy of science to science policy. Technology in Society, 2019.

[7] Isabel Busom and Jorge Andrés Vélez-Ospina. Innovation, public support, and productivity in colombia. a cross-industry comparison. World Development, 99:75 - 94, 2017.

[8] Jonathan Calderon-Rojas. Etapas del conflicto armado en colombia: hacia el posconflicto. Latinoamerica. Revista de estudios Latinoamericanos, pages 227 - 257, 062016 .

[9] Samwel Macharia Chege, Daoping Wang, Shaldon Leparan Suntu, and Obadia Kyetuza Bishoge. Influence of technology transfer on performance and sustainability of standard gauge railway in developing countries. Technology in Society, 56:79 - 92, 2019.

[10] Edwin Cruz-Rodriguez. Los estudios sobre el paramilitarismo en colombia. http://www.scielo.org.co/scielo.php?script $=$ sci $i_{a}$ rttextpid $=S 0121-$ 47052007000200006lng $=$ ennrm $=$ iso, $20: 117--134,2007$.

[11] John de la Mothe. The revision of international science indicators:: The frascati manual. Technology in Society, 14(4):427 - 440, 1992.

[12] Ben D'Exelle, Eric Coleman, and Maria Claudia Lopez. Communitydriven reconstruction in colombia: An experimental study of collective action beyond program beneficiaries. World Development, 101:188-201, 2018

[13] José Fernández-Leost. La cooperación internacional para el desarrollo, una aproximación teórico-política. CeaLCI- Fundación Carolina, (9):33, 2010.

[14] Ellen-Marie Forsberg, GianLuca Quaglio, Hannah O'Kane, Theodoros Karapiperis, Lieve Van Woensel, and Simone Arnaldi. Assessment of science and technologies: Advising for and with responsibility. Technology in Society, 42:21 - 27, 2015

[15] Juana García. Cooperación internacional y posconflicto en colombia: más allá de los recursos económicos. Revista Sexante Universidad de los Andes, 5:https://sextante.uniandes.edu.co/index.php/ejemplares/sextante5/horizontes/cooperacion-internacional-y-posconflicto-en-colombia, 2015.

[16] Scott Gates, Håvard Hegre, Håvard Mokleiv Nygård, and Håvard Strand. Development consequences of armed conflict. World Development, 40(9):1713 - 1722, 2012.

[17] Ramesh Ghimire, Susana Ferreira, and Jeffrey H. Dorfman. Floodinduced displacement and civil conflict. World Development, 66:614 $628,2015$.

[18] Jorge Giraldo-Ramirez, Alberto Naranjo, Ana Jaramillo, and Gustavo Ducan. Economía criminal en antioquia: Narcotrafico (2011). http://www.eafit.edu.co/centros/analisis-politico/publicaciones/proyectosinvestigacion/Documents/libro\%20Economia\%20Criminal.pdf, FONDO EDITORIAL UNIVERSIDAD EAFIT. Materia: CIENCIAS POLITICAS, 2011.

[19] Nils Petter Gleditsch, Steven Pinker, Bradley A. Thayer, Jack S. Levy, and William R. Thompson. The Forum: The Decline of War. International Studies Review, 15(3):396-419,09 2013

[20] Bradford Goldense. Technology readiness levels are widely adopted [a133]. Machine Design, Volume 89:64, 052017.

[21] Jennifer S. Holmes, Agustin Palao Mendizabal, David Saucedo De La Fuente, Mercedez Callenes, and Álvaro Cárdenas. Paramilitary violence in colombia: A multilevel negative binomial analysis. Defence and Peace Economics, 0(0):1-27, 2019.

[22] Ana María Ibáñez and Andrés Moya. Vulnerability of victims of civil conflicts: Empirical evidence for the displaced population in colombia. World Development, 38(4):647 - 663, 2010.

[23] Rouben Indjikian and Donald S. Siegel. The impact of investment in it on economic performance: Implications for developing countries. World Development, 33(5):681 - 700, 2005.

[24] Alfonso Insuasty Rodriguez, Eulalia Bedoya, Yeny Mesa Duque, Yani Duque, and Héctor Alejandro Cometa. Falsos positivos 2.0 y paramilitarismo 4g: ¿el aceite del "desarrollo"? colombia, 062019

[25] Alfonso Insuasty-Rodriguez, Jose Valencia-Grajales, and Janeth Restrepo-Marin. Elementos para una genealogía del paramilitarismo en colombia: historia y contexto de la ruptura y continuidad del fenómeno (2016).
http://biblioteca.clacso.edu.ar/Colombia/kavilando/20170210032121/0.pdf, 2016.

[26] ANA M. ROMERO-MARTINEZ, Angeles Montero-Sanchez, and Youseline Garavito. The efect of gender diversity and education level on innovation. Revista de Administração de Empresas, 57:123-134, 042017.

[27] Jorge H. Maldonado, Rocío del Pilar Moreno-Sánchez, Sophía Espinoza, Aaron Bruner, Natalia Garzón, and John Myers. Peace is much more than doves: The economic benefits of bird-based tourism as a result of the peace treaty in colombia. World Development, 106:78 - 86, 2018.

[28] Alberto Martin-Alvarez and Eduardo Rey-Tristan. La dimension transnacional de la izquierda armada. http://revistas.usal.es/index.php/11302887/article/view/alh201880828/19931, 80:9 - 28, 2015.

[29] Andrés Moya and Michael R. Carter. Violence and the formation of hopelessness: Evidence from internally displaced persons in colombia. World Development, 113:100 - 115, 2019.

[30] Juan Carlos Muñoz-Mora, Santiago Tobón, and Jesse Willem d'Anjou. The role of land property rights in the war on illicit crops: Evidence from colombia. World Development, 103:268 - 283, 2018.

[31] Duncan Pedersen. Political violence, ethnic conflict, and contemporary wars: broad implications for health and social well-being. Social Science Medicine, 55(2):175 - 190, 2002.

[32] Paola Pena, Joaquin Urrego, and Juan M. Villa. Civil conflict and conditional cash transfers: Effects on demobilization. World Development, 99:431 - 440, 2017.

[33] K. De Pourcq, E. Thomas, B. Arts, A. Vranckx, T. Léon-Sicard, and P. Van Damme. Understanding and resolving conflict between local communities and conservation authorities in colombia. World Development, 93:125 - 135, 2017

[34] Angelika Rettberg and Angela Rivas. El sector empresarial y la construccion de paz en Colombia: entre el optimismo y el desencanto, pages 305-348. 012012.

[35] Catherine rodríguez and fabio sánchez. Armed conflict exposure, human capital investments, and child labor: Evidence from colombia. Defence and Peace Economics, 23(2):161-184, 2012.

[36] Mauricio A. Rodríguez and Nancy A. Daza. Determinants of civil conflict in colombia: How robust are they? Defence and Peace Economics, 23(2):109-131, 2012

[37] Gonzalo Sanchez-Gomez. Guerra y política en la sociedad colombiana. https://revistas.unal.edu.co/index.php/anpol/article/view/74324, 11:7 - 27, 1990.

[38] Diane Tawse-Smith. Conflicto armado colombiano. desafios. https://revistas.urosario.edu.co/index.php/desafios/article/view/413/355, 19:269 - 299, 2008.

[39] Juan F. Vargas. The persistent colombian conflict: subnational analysis of the duration of violence. Defence and Peace Economics, 23(2):203-223, 2012.

[40] John Vásquez. Relación industria - universidad. clave para el desarrollo tecnológico, en colombia. INVENTUM, 39:77-83, 052008.

[41] Xiuli Xu, Xiaoyun Li, Gubo Qi, Lixia Tang, and Langton Mukwereza. Science, technology, and the politics of knowledge: The case of china's agricultural technology demonstration centers in africa. World Development, 81:82 - 91, 2016. China and Brazil in African Agriculture. 